\title{
Where does selective laser trabeculoplasty stand now? A review
}

\author{
Myrjam De Keyser ${ }^{1,2^{*}}$ D, Maya De Belder ${ }^{3}$, Simon De Belder ${ }^{1}$ and Veva De Groot ${ }^{1,4}$
}

\begin{abstract}
Background: Chronic treatment of glaucoma can present a challenge in patients who lack the means and/or the discipline to use daily glaucoma medication. We wondered if selective laser trabeculoplasty (SLT) could be a useful alternative.

Methods: Inclusion criteria: controlled trials comparing efficacy of SLT in adult patients with any form of open angle glaucoma or ocular hypertension and case reports on side effects of SLT. Two recent meta-analyses identified eight randomized clinical trials (RCTs) comparing the effect of SLT with medication (prostaglandin analogs) and with argon laser trabeculoplasty (ALT). We took these eight RCTs as reference base and calculated their success rates where they were not given. Other articles were added to elaborate on technique and side effects.

Results: Mean intraocular pressure (IOP) reduction after SLT was 3.8-8.0 mmHg after 6 months to 1 year. Mean success rate of SLT at 6 months to 1 year is 55-82 \%. Higher IOP before laser predicts a higher IOP-lowering effect. In terms of mean IOP reduction, reduction in number of medications and treatment success, the effect of SLT was found to show no clinically relevant difference from that of contemporary medication (prostaglandin analogs) and from ALT.
\end{abstract}

Conclusions: The evidence indicates that SLT is an efficacious primary or adjunctive therapy for treating glaucoma.

Keywords: Glaucoma, Selective laser trabeculoplasty, Review, Open angle glaucoma, Glaucoma treatment, Ocular hypertension

\section{Background}

Glaucoma is a multifactorial disease $[1,2]$ characterized by damage to the optic nerve, often caused by an elevated intraocular pressure (IOP). Worldwide, it is the second leading cause of blindness, following cataract. It is predicted that by 2020, 79.6 million people will have glaucoma [3], of which $74 \%$ will be open angle glaucoma (OAG) $[4,5]$.

The aim of glaucoma therapy is lowering the IOP in order to slow down glaucoma progression. Currently, this goal can be achieved by medication, laser treatment or surgery [6]. Eye drops are typically the first line of therapy for glaucoma. However, topical agents and preservatives in glaucoma medication can produce local and systemic side effects $[1,4,5,7]$. Patients must also tolerate repeat application of drugs and on-going medical costs [8].

\footnotetext{
* Correspondence: Myrjam@bijzonder.be

${ }^{1}$ Department of Medicine, University of Antwerp, Universiteitsplein 1, B-2610 Antwerp, Belgium

${ }^{2}$ Medipolis, Boomsesteenweg 223, B-2610 Antwerp, Belgium

Full list of author information is available at the end of the article
}

Adherence poses a problem [9]. At best, treatment adherence in chronic diseases is estimated to be $75 \%[6,10]$. More complex dosing regimens, as common in glaucoma, result in poorer adherence $[4,8,9,11]$. Administering topical medications is often problematic for elderly patients who need assistance to administer the drops or miss the eye and waste expensive medication [12]. Not properly using the prescribed drops is a major cause of visual loss in patients with glaucoma [12].

As an alternative to eye drops, argon laser trabeculoplasty (ALT) $[13,14]$ has proven to be a useful treatment. ALT produces much coagulative damage on biomicroscopy [15] and probably works mechanically through shrinking the trabecular meshwork (TM) tissue at the coagulation site and opening up the adjacent tissue. However, Bylsma et al. showed that ALT also activates a cellular mechanism that stimulates TM cell division, rejuvenating the meshwork [16]. Secretion of interleukins after ALT has also been 
demonstrated, stimulating remodelling of the extracellular matrix and lowering resistance at the TM [17].

Long-term follow-up showed that after a few years, 68$95 \%$ of patients returned to a higher IOP. Retreatment with ALT was found to be ineffective $[12,18,19]$.

Selective laser trabeculoplasty (SLT) was launched in 1998 by Latina et al. [20]. A frequency-doubled, Qswitched, $532 \mathrm{~nm}$ Nd:YAG laser is used with pulse duration of $3 \mathrm{nsec}$ and a spot size of $400 \mu \mathrm{m}$. This pulse duration is too short for melanin to convert the electromagnetic energy to thermal energy, which means that no heat is generated. The total energy per $\mu \mathrm{m}$ of spotsize in SLT is more than 6500 times lower than in ALT, which provides a theoretical basis to consider SLT as a repeatable treatment for lowering IOP.

In our public hospital, we have a 'difficult' population; there is a tendency for irregular follow up examinations (no show) because of lack of means and mostly of discipline to use glaucoma medication, which compromises therapy. Laser could be a non-invasive treatment that can partly solve these problems. The question our patients always ask when we try to motivate them to have SLT done is: 'What are my chances that this laser will work and what problems can I expect from this laser?' This article sets out to answer those questions in terms of success rate and side effects of SLT.

\section{Methods}

\section{Literature search and trial selection}

Studies were identified and retrieved through a systematic search of PubMed, Web of Science and Google Scholar. Keywords used in identifying relevant research included 'selective laser trabeculoplasty, 'SLT, 'glaucoma treatment', 'ocular hypertension' and 'side effects of selective laser trabeculoplasty'.

Inclusion criteria: retrospective and prospective comparative controlled trials studying the effect of SLT in adult patients with any form of OAG or ocular hypertension (OHT), with or without medication. We also included case-reports on side effects of SLT.

Exclusion criteria: studies in which SLT was used as adjunct for glaucoma operations.

Recently, two meta-analyses were published on SLT. A meta-analysis by $\mathrm{Li}$ et al. [8] identified four randomized clinical trials (RCTs) comparing the effect of SLT with medication [21-24]. The meta-analysis of Wong et al. [25] included these four RCTs and four additional RCTs, that compared SLT to ALT [26-29]. These eight RCTs were taken as reference base for our calculations. Other articles were used to elaborate on technique and side effects.

The information on author, mean age, sample size, type of glaucoma, and study design were extracted. We calculated the success rate if it was not given in the article and when enough data were present to make this calculation $[21,22,26]$. Definition of success was a $20 \%$ lowering of IOP compared to baseline IOP. Where mentioned, the incidence of transient post-laser IOP spikes, redness, anterior chamber reaction, discomfort or other side effects were recorded.

\section{Review \\ Mechanism}

Cvenkel et al. applied ALT to a part of the eye, and SLT to another part of the same eye in three patients that were planned to get an enucleation [15]. After the enucleation, the anterior segments of the eyes were dissected and examined. Light microscopy and transmission electron microscopy showed much less structural changes after SLT than after ALT. Damaging the pigmented cells of the TM without mechanical or thermic effect by SLT seemed to be enough to enhance the outflow through the TM. This may be a sign that SLT works more at a cellular level, through stimulation of the formation of healthy TM tissue, like ALT [16, 17, 30]. Detorakis et al. also found arguments for a biochemical mechanism with release of cytokines after laser that possibly attract macrophages and stimulate phagocytosis of debris in the TM [31]. Both cellular and biomechanical mechanisms can enhance the outflow capacity of the TM with minimal damage to the tissue $[15,32]$.

\section{Characteristics of intervention}

In the eight reference RCTs of Wong et al. [25] and Li et al. [8], 45-102 SLT applications were applied, with a spot size of $400 \mu \mathrm{m}$ and power between 0.47 and $1.7 \mathrm{~mJ}$, with each spot lasting 3 ns. See also Table 1.

In the 2005 study, Nagar et al. [23] randomized patients to 90,180 , and $360^{\circ}$ treatment. The $90^{\circ}$ had a very low success rate at a mean of 10.3 months (34\%). Although there was no statistically significant difference in outcome after $180^{\circ}$ or $360^{\circ}$ of SLT treatment, success rates were better with $360^{\circ}$. In their trial, Bovell et al. [26], Liu et al. [27], Rosenfeld et al. [28], and Kent et al. [29] chose to treat $180^{\circ}$ of the TM. Lai et al. [22], Nagar et al. [23], and Katz et al. [21] treated $360^{\circ}$. Katz et al. started by treating $360^{\circ}$ and performed a $180^{\circ}$ treatment when a second SLT was needed during follow up.

The energy level used is titrated to the degree of trabecular pigmentation. The greater the pigmentation, the less energy is required. To determine the optimal energy level, the power setting is initially set at $0.6-0.9 \mathrm{~mJ}$ and the energy level is increased by $0.1 \mathrm{~mJ}$ until bubble formation (champagne bubbles) is observed. If bubble formation is already noted at the initial energy level, the laser energy is reduced by $0.1 \mathrm{~mJ}$ [20]. An energy level just below that of bubble formation is then maintained. In their population of pseudoexfoliative syndrome (PEX) 
Table 1 Baseline characteristics of randomized clinical trials using SLT

\begin{tabular}{|c|c|c|c|c|c|c|c|c|c|}
\hline $\begin{array}{l}\text { Author, } \\
\text { year }\end{array}$ & $\begin{array}{l}\text { Design, } \\
\text { location }\end{array}$ & Type of glaucoma & $\begin{array}{l}\text { \# eyes } \\
\text { after SLT }\end{array}$ & $\begin{array}{l}\text { Treatment in } \\
\text { control arm }\end{array}$ & $\begin{array}{l}\text { Mean follow- } \\
\text { up (months) }\end{array}$ & $\begin{array}{l}\text { Mean age } \\
\text { (years) }\end{array}$ & $\begin{array}{l}\text { SLT group baseline IOP } \\
(\mathrm{mmHg})\end{array}$ & $\begin{array}{l}\text { Control group baseline IOP } \\
(\mathrm{mmHg})\end{array}$ & $\begin{array}{l}\text { Characteristics SLT (extent, } \\
\text { number spots, power) }\end{array}$ \\
\hline $\begin{array}{l}\text { Lai, } 2004 \\
{[22]}\end{array}$ & $\begin{array}{l}\text { SC, } \\
\text { China }\end{array}$ & POAG, OHT & 29 & $\begin{array}{l}\text { medication } \\
\text { (not specified) }\end{array}$ & 60 & $51.9 \pm 14.7$ & $26.8 \pm 5.6$ & $26.2 \pm 4.2$ & $360^{\circ}, 100,1.0 \pm 0.1 \mathrm{~mJ}$ \\
\hline $\begin{array}{l}\text { Nagar, } \\
2005[23]\end{array}$ & $M C, U K$ & POAG, OHT, PEX, PDS & 128 & $\begin{array}{l}\text { medication } \\
\text { (lat) }\end{array}$ & 10.3 & 63 & NA & NA & $\begin{array}{l}90^{\circ} \text { (25-30 spots), } \\
180^{\circ} \text { (48-53 spots), } \\
360^{\circ} \text { (93-102 spots), } \\
0.8-1.7 \mathrm{~mJ}\end{array}$ \\
\hline $\begin{array}{l}\text { Nagar, } \\
2009[24]\end{array}$ & SC, UK & POAG, OHT & 20 & $\begin{array}{l}\text { medication } \\
\text { (lat) }\end{array}$ & $4-6$ & 66.4 & $26.1 \pm 4.0$ & $22.8 \pm 4.5$ & $360^{\circ}, 100 \pm 5,0.8-1.4 \mathrm{~mJ}$ \\
\hline $\begin{array}{l}\text { Katz, } 2012 \\
{[21]}\end{array}$ & MC, USA & POAG, OHT & 67 & $\begin{array}{l}\text { medication } \\
\text { (prost) }\end{array}$ & $6-12$ & NA & $\begin{array}{l}25.0 \pm 2.2 \text { (4-6 mth group), } \\
24.5 \pm 2.1 \text { (9-12 mth group) }\end{array}$ & $\begin{array}{l}24.5 \pm 2.2 \text { (4-6 mth group), } \\
24.7 \pm 2.4 \text { (9-12 mth group) }\end{array}$ & $360^{\circ}, 100,0.8-1.2 \mathrm{~mJ}$ \\
\hline $\begin{array}{l}\text { Bovell, } \\
2011[26]\end{array}$ & $\begin{array}{l}\text { SC, } \\
\text { Canada }\end{array}$ & $\begin{array}{l}\text { POAG, PEX, PDS, mix } \\
\text { mech, others }\end{array}$ & 89 & ALT & 60 & $69.7 \pm 10.52$ & $23.8 \pm 4.9$ & $23.48 \pm 4.21$ & $180^{\circ}, 50,0.47-1.5 \mathrm{~mJ}$ \\
\hline $\begin{array}{l}\text { Liu, } 2012 \\
{[27]}\end{array}$ & $\begin{array}{l}\text { SC, } \\
\text { Canada }\end{array}$ & $\begin{array}{l}\text { POAG, OHT, PEX, PDS, } \\
\text { NTG, juv OAG, mix mech }\end{array}$ & 20 & ALT & 37 & $48.7 \pm 9.4$ & $19.1 \pm 4.5$ & $21.9 \pm 4.4$ & $180^{\circ}, 45-55,0.7-0.8 \mathrm{~mJ}$ \\
\hline $\begin{array}{l}\text { Rosenfeld, } \\
2012[28]\end{array}$ & SC, Israel & POAG, OHT, PEX, PDS & 22 & ALT & 12 & 71.95 & $25.36 \pm 1.83$ & $25.11 \pm 2.16$ & $180^{\circ}, 50-70,0.8-1.2 \mathrm{~mJ}$ \\
\hline $\begin{array}{l}\text { Kent, } 2013 \\
{[29]}\end{array}$ & $\begin{array}{l}\text { MC, } \\
\text { Canada }\end{array}$ & PEX & 37 & ALT & 6 & $72.9 \pm 9.86$ & $23.1 \pm 4.22$ & $25.2 \pm 4.87$ & $180^{\circ}, 53 \pm 3.75,0.6 \mathrm{~mJ}$ \\
\hline
\end{tabular}

Abbreviations: $S C=$ single centre; $M C=$ multicentre; $N A=$ not available; $P O A G=$ primary open angle glaucoma; $O H T=$ ocular hypertension; $P D S=$ pigment dispersion syndrome; $P E X=$ pseudoexfoliation syndrome; NTG = normal tension glaucoma; juv = juvenile glaucoma; mix mech = mixed mechanism glaucoma; lat = latanoprost; prost $=$ prostaglandin analog 
patients, Kent et al. used a mean energy level of $0.6 \mathrm{~mJ}$ [29] for their population of pseudoexfoliation glaucoma patients.

Ayala et al. [33] found that higher energy creates a longer IOP lowering effect after SLT and Lee et al. [34] also suggested using a higher energy density (number of spots multiplied by mean energy) to improve SLT outcome. On the other hand, more energy and more spots may be associated with more side effects [23] and an increased risk of corneal oedema [35], so caution has to be taken.

It may be important to bring in mind that the energy used in SLT is much lower than in ALT. SLT classically uses around $0,9 \mathrm{~mJ}$ of energy [23-25], whereas ALT uses around $50 \mathrm{~mJ}(500 \mathrm{~mW}$ for $0.1 \mathrm{~s})$ [26-28]. This makes the energy used by SLT 55 times smaller than in ALT. The laser spot used in SLT has a diameter of $400 \mu \mathrm{m}$ [23-25] or an area of $0.13 \mathrm{~mm}^{2}$. ALT uses a spot of $50 \mu \mathrm{m}[26-28]$ or an area of $0.002 \mathrm{~mm}^{2}$. The energy in ALT is thus aimed at an area 64 times smaller than in SLT. This means that the energy per $\mathrm{mm}^{2}$ of tissue is 3520 times smaller in SLT than in ALT.

\section{Comparison of SLT to medication}

The effectiveness of SLT compared to contemporary medication (prostaglandin analogs) was investigated in a large meta-analysis by Li et al. [8]. Five prospective studies were included in their study, four randomized and one non-randomized. Wong et al. identified the same four randomized RCTs. We included these four studies, one published by Lai et al. [22], two by Nagar et al. [23, 24], and one by Katz et al. [21]. Two of them were single centre, while the others were multicentre trials, see Table 1. The number of patients treated with SLT ranged from 20 to 67; the largest trial by Nagar et al. included 128 eyes [23]. Mean follow up time was short: 4 to 12 months. Lai [22] and Bovell [26] had a follow up time of 5 years. The study of Nagar [23] mentioned a range of follow up from 1 to 12 months. In this study, patients were randomized to medication and $90^{\circ}, 180^{\circ}$, and $360^{\circ}$ of SLT. The second trial of Nagar et al. [24] was designed to compare the effect of reduction of IOP fluctuation between SLT and latanoprost, with a mean follow up of 4 to 6 months. This study showed a significantly higher baseline IOP in the latanoprost group, which was adjusted for calculation of the IOP fluctuation. Baseline IOP was above $24.5 \mathrm{mmHg}$ in three of the four RCTs (not available in Nagar [23]). No significant differences in IOP lowering effect could be found between the medication and the SLT groups.

\section{Comparison of SLT to ALT}

Wong et al. [25] conducted a meta-analysis involving all studies on SLT effect in patients with OAG or OHT. They included primary open angle glaucoma (POAG),
PEX, pigment dispersion syndrome (PDS), uveitis glaucoma, juvenile glaucoma, steroid-induced glaucoma, and normal tension glaucoma. Four RCTs comparing the efficacy of SLT and ALT were identified. These studies were conducted between 2011 and 2013, which included one multicentre and 3 single centre trials. Baseline characteristics are shown in Table 1. The number of patients treated was again mostly limited (20-37) with one larger study ( 89 patients) by Bovell et al. [26]. Liu et al. focused on younger patients, with a mean age of 48.7 years and a significantly lower baseline IOP $(19.1 \mathrm{mmHg})$. Rosenfeld et al. [28] recruited patients that underwent successful cataract extraction 3-6 months before the study commenced. Kent et al. [29] limited their study to patients with PEX. All studies concluded that the IOP-lowering effect of SLT was comparable to ALT.

\section{Success rate}

The IOP reduction varied from 3.8 to $8.0 \mathrm{mmHg}$ at 6 months to 1 year after SLT (see Table 2). The lowest reduction of $3.8 \mathrm{mmHg}$ was found in the population of Liu et al. [27]. This group started with a low mean baseline IOP $(19.1 \mathrm{mmHg})$. As a higher baseline IOP is predictive of a greater IOP decrease, a lower response could be expected.

Five studies used 'more than $20 \%$ reduction of the IOP compared to baseline IOP' as their definition of success (Lai et al. [22], Nagar et al. [23, 24], Bovell et al. [26], Kent et al. [29]). Their success rates at 6 months to 1 year varied from 55 to $82 \%$. Again, Liu et al. reported the lowest success rate. This result is in line with trials that claim SLT can be used to lower IOP in normal tension glaucoma, but rarely (in $22 \%$ of patients) creates an IOP reduction of more than $20 \%$ [36]. The success rate of the group that was treated over $90^{\circ}$ of TM by Nagar was the lowest recorded; this treatment was considered as insufficient [23]. Lai [22], Katz [21] and Rosenfeld [28] reported success rates ranging from 75 to $97 \%$ after 6 months to 1 year, but used criteria of success that deviated from the others and appear less stringent (IOP less than $21 \mathrm{mmHg}$ [22], IOP less than $2 \mathrm{mmHg}$ above target IOP [21] or more than $15 \%$ IOP reduction [28].

Prediction of success of SLT was examined in several trials and has proven indifferent to: gender, race [23], family history, other glaucoma risk factors, type and severity of OAG, TM pigmentation [19, 37], pseudo-exfoliation [18], number and type of anti-glaucoma medications [22, 38], previous laser [26, 39], phakic or pseudophakic eyes [40], patent iridotomy [41], presence of systemic hypertension or diabetes mellitus $[9,42]$.

The only variable that predicts a better IOP-lowering effect after SLT is a higher IOP prior to laser [5, 18, 43, 44]. One study found shortened time to failure with increasing age [33], but this was not confirmed by others. Lee et al. 
Table 2 Results of the randomized clinical trials using SLT

\begin{tabular}{|c|c|c|c|c|c|c|c|}
\hline $\begin{array}{l}\text { Author, } \\
\text { year }\end{array}$ & $\begin{array}{l}\text { SLT IOP red (mmHg) } \\
\text { at } 6 \mathrm{~m}-1 \text { y (months) }\end{array}$ & $\begin{array}{l}\text { SLT IOP red (mmHg) } \\
\text { end of study (months) }\end{array}$ & $\begin{array}{l}\text { Control group IOP red } \\
\text { (mmHg) at } 6 \mathrm{~m}-1 \text { y } \\
\text { (months) }\end{array}$ & $\begin{array}{l}\text { Control group IOP red } \\
\text { (mmHg) end of study } \\
\text { (months) }\end{array}$ & SLT definition of success & $\begin{array}{l}\text { SLT success rate at } \\
6 \mathrm{~m}-1 \text { y }(\%) \\
\text { (months) }\end{array}$ & $\begin{array}{l}\text { SLT success rate at end } \\
\text { of study (\%) (months) }\end{array}$ \\
\hline $\begin{array}{l}\text { Lai, } 2004 \\
{[22]}\end{array}$ & $8.0(12)$ & $8.6 \pm 6.7(60)$ & $7.0(12)$ & $8.7 \pm 6.6(60)$ & $\mathrm{IOP}<21 \mathrm{mmHg}$ & 97 & $72.41(60)$ \\
\hline \multirow{3}{*}{$\begin{array}{l}\text { Nagar, } \\
2005[23]\end{array}$} & \multirow[t]{3}{*}{ NA } & \multirow[t]{3}{*}{ - } & \multirow[t]{3}{*}{ NA } & \multirow[t]{3}{*}{ - } & \multirow[t]{3}{*}{$>20 \%$ IOP red } & $90^{\circ}=34$ & \multirow[t]{3}{*}{ - } \\
\hline & & & & & & $180^{\circ}=65$ & \\
\hline & & & & & & $360^{\circ}=82(10)$ & \\
\hline $\begin{array}{l}\text { Nagar, } \\
2009[24]\end{array}$ & $6.2 \pm 0.8(4-6)$ & - & $7.8 \pm 0.8(4-6)$ & - & $>20 \%$ IOP red & $75(4-6)$ & - \\
\hline $\begin{array}{l}\text { Katz, } 2012 \\
{[21]}\end{array}$ & $6.3 \pm 2.7(12)$ & - & $7.0 \pm 1.8(12)$ & - & $\begin{array}{l}\text { IOP } \leq 2 \mathrm{mmHg} \text { above } \\
\text { target IOP }+ \text { no VF loss } \geq 3 \\
\text { unit }\end{array}$ & $80(12)$ & - \\
\hline $\begin{array}{l}\text { Bovell, } \\
2011 \text { [26] }\end{array}$ & $6.0 \pm 6.1(12)$ & $7.4 \pm 7.3(60)$ & $6.0 \pm 4.8(12)$ & $6.7 \pm 6.6(60)$ & $>20 \%$ IOP red & $71(12)$ & $25(60)$ \\
\hline \multirow{2}{*}{$\begin{array}{l}\text { Liu, } 2012 \\
{[27]}\end{array}$} & \multirow[t]{2}{*}{$3.8(12)$} & \multirow[t]{2}{*}{$1.8(24)$} & \multirow[t]{2}{*}{$2.7(12)$} & \multirow[t]{2}{*}{$2.8(24)^{\mathrm{a}}$} & def 1: > $20 \%$ IOP red & \multirow[t]{2}{*}{$55(12)$} & def 1: $40(24)^{a}$ \\
\hline & & & & & def 2: IOP < target IOP & & $\operatorname{def} 2: 75(24)^{a}$ \\
\hline $\begin{array}{l}\text { Rosenfeld, } \\
2012[28]\end{array}$ & $4.3(12)$ & - & $3.23(12)$ & - & $\geq 15 \%$ IOP red & $75(12)$ & - \\
\hline $\begin{array}{l}\text { Kent, } 2013 \\
{[29]}\end{array}$ & $6.8(6)$ & - & $7.0(6)$ & - & $>20 \%$ IOP red & $73(6)$ & - \\
\hline
\end{tabular}

Abbreviations: IOP red = IOP reduction; $m=$ months; $y=$ year; $N A=$ not available; red = reduction; $V F=$ visual field; def = definition; end of study = when study was longer than 12 months

${ }^{a}$ Results of Liu et al. [27] at end of study (37 months) were not available 
[34] also found a significant correlation between both eyes in almost $80 \%$ of treated OAG subjects; success after SLT in one eye correlates with a higher chance of success in the other, which has been confirmed by Shazly et al. [45]. Thinner corneas $(\mathrm{CCT}<555 \mu \mathrm{m})$ also seemed to give better IOP reduction after SLT [46, 47].

\section{Long term effect}

The effect of ALT diminishes over time and the 5-year success rate is reported to be about $50 \%$ [26]. Longterm effectiveness of SLT seems to show similar results. Bovell et al. [26] started with a $71 \%$ success rate at 1 year, which decreased to $52 \%$ at 2 years, $44 \%$ at 3 years, $38 \%$ at 4 years, and $25 \%$ at 5 years. Lai et al. [22] reported a success rate of $97 \% 1$ year after SLT and $72 \% 5$ years after SLT, but as noted; their definition of success was less stringent (IOP below $21 \mathrm{mmHg}$ ).

The usefulness of SLT and its possible cost-efficient character $[12,48]$ thus relies upon its repeatability. Hong et al. [39] published one of the first studies on repeat SLT. They examined the effect of a second SLT over $360^{\circ}$ in patients who underwent an initial $360^{\circ}$ SLT that was successful for more than 6 months but eventually lost efficacy. They recorded no significant difference between treatments and equal success rates after the first and the second SLT. They also compared the group of patients who had a second SLT after 6 months with a group that only needed a second SLT after 12 months and found no differences. They concluded a repeat SLT could be performed as soon as 6 months after a successful first SLT. Ayala et al. [42] treated only $180^{\circ}$ of the TM and examined if repeat SLT had better results when it was performed in another area as the first SLT. After a failed SLT, they randomized patients to receive a second SLT in the same or in a different area than the first SLT. This made no difference, which supports the minimal damage theory.

\section{Side effects of SLT}

Redness, discomfort and anterior chamber reaction in the first week after SLT are very common. Nagar et al. [23] recorded discomfort and pain in the first week in $6 \%$ of the patients that underwent $90^{\circ}$ SLT, $20 \%$ after $180^{\circ}$, and $39 \%$ after $360^{\circ}$. Anterior chamber reaction/ uveitis was present in $31 \%$ of patients after $90^{\circ} \mathrm{SLT}$, $41 \%$ after $180^{\circ}$, and $50 \%$ after $360^{\circ}$ treatment. These adverse effects are common but much less pronounced than after ALT [49]. Seven of the RCTs used steroids or non-steroidal anti-inflammatory drops after SLT to diminish the side effects (see Table 3). Katz et al. [21] did not mention the use of pre- or post laser drops. Other short lived side effects include headache, photophobia, corneal abrasion, pigment dispersion and subconjunctival haemorrhage [25].

\section{IOP spike}

The transient IOP spike after laser trabeculoplasty is supposed to be dependent upon the energy used per pulse and the total energy administered [50]. Since SLT uses much less energy than ALT, per pulse $(0.9 \mathrm{~mJ}$ compared to $50 \mathrm{~mJ}$ ) the IOP-rise is much less common and less pronounced [26-28,49]. Still, a short increase of more than $5 \mathrm{mmHg}$ above baseline IOP was recorded in 4.5-27\% of patients in three of the RCTs (Lai et al. [22], Nagar et al. [23] and Bovell et al. [26]).

As in ALT [50], a drop of apraclonidine [22, 33, 39, 51-53] or brimonidine [54-56] before and immediately after SLT can be used to prevent the IOP-spike. Seven of the RCTs mentioned the use of apraclonidine, amethocaine, or brimonidine prior to SLT. If IOP elevation did occur, it was treated with anti-glaucoma medication.

\section{Corneal changes}

Transient corneal thinning and changes in endothelial cell count seem common after SLT, with recovery to normal after one month $[57,58]$. In the eight RCTs, no other complications after SLT were noticed. Other studies reported on some rare corneal changes: two cases of transient corneal oedema [59] and one case of corneal decompensation [60] after SLT have been described.

Knickelbein et al. [35] reported 4 cases of corneal hydrops, a condition characterized by acute corneal oedema followed by stromal thinning. Their findings suggest that SLT induces cytokine production and activation of matrix metalloproteinases, which are also involved in destructive inflammatory responses and can enhance collagen degeneration by corneal fibroblasts.

\section{Cystoid macular oedema}

Two cases of cystoid macular oedema [61, 62] have been reported, but it is suggested that this kind of complication is related to previous complicated lens-surgery. Caution would be needed in patients after compromised cataract surgery. Other very rare complications that have been reported include one case of iritis and choroidal effusion [63] and two cases of hyphema [64] after SLT.

\section{Conclusions}

Robust evidence was presented that there is no significant difference in IOP lowering effect between medication and SLT or between ALT and SLT. At 6 months to 1 year, the success rate of SLT varied between 55 and $82 \%$. Higher baseline IOP is correlated to higher IOP lowering effect of SLT.

Side effects of SLT are minor. A transient IOP spike is common. Apraclonidine, amethocaine, or brimonidine drops can be administered before and immediately after SLT to counter this IOP rise. More severe side effects like corneal or macular oedema, peripheral anterior 
Table 3 Side effects mentioned in the randomized clinical trials using SLT

\begin{tabular}{|c|c|c|c|c|c|c|c|c|}
\hline Author, year & $\begin{array}{l}\text { Drops administered before } \\
\text { SLT }\end{array}$ & $\begin{array}{l}\text { Drops administered after } \\
\text { SLT }\end{array}$ & $\begin{array}{l}\text { Redness First } \\
\text { week }\end{array}$ & $\begin{array}{l}\text { Discomfort First } \\
\text { week }\end{array}$ & $\begin{array}{l}\text { Anterior chamber reaction First } \\
\text { week }\end{array}$ & $\begin{array}{l}\text { Definition IOP } \\
\text { spike }\end{array}$ & $\begin{array}{l}\text { IOP spike } \\
(\%)\end{array}$ & $\begin{array}{l}\text { Other side- } \\
\text { effects }\end{array}$ \\
\hline Lai, 2004 [22] & apra & apra $1 x+$ pred $4 x, 7 d$ & yes & NA & yes & $>5 \mathrm{mmHg}$ & 10 & none \\
\hline Nagar, 2005 [23] & ameth & dex or keto $4 x, 5 d$ & NA & $\begin{array}{l}90^{\circ}=6 \% \\
180^{\circ}=20 \% \\
360^{\circ}=39 \%\end{array}$ & $\begin{array}{l}90^{\circ}=31 \% \\
180^{\circ}=41 \% \\
360^{\circ}=50 \%\end{array}$ & $\geq 5 \mathrm{mmHg}$ & $\begin{array}{l}90^{\circ}=9 \% \\
180^{\circ}=16 \% \\
360^{\circ}=27 \%\end{array}$ & none \\
\hline Nagar, 2009 [24] & ameth & keto $4 x, 5 d$ & NA & NA & NA & NA & NA & NA \\
\hline Katz, 2012 [21] & NA & NA & NA & NA & NA & NA & NA & none \\
\hline Bovell, 2011 [26] & apra or brim & pred $4 x, 5 d$ & NA & NA & NA & $\geq 6 \mathrm{mmHg}$ & 4.5 & NA \\
\hline Liu, 2012 [27] & brim & fluoro $4 x, 5 d$ & NA & NA & NA & NA & none & none \\
\hline $\begin{array}{l}\text { Rosenfeld, } 2012 \\
\text { [28] }\end{array}$ & apra & $\operatorname{dex} 3 x, 7 d$ & NA & NA & NA & NA & NA & none \\
\hline Kent, 2013 [29] & brim + pilo & keto $4 x, 5 d$ & NA & NA & NA & $>6 \mathrm{mmHg}$ & NA & NA \\
\hline
\end{tabular}

Abbreviations: NA = not available; apra $=1 \%$ apraclonidine; pred $=1 \%$ prednisolone acetate; ameth $=1 \%$ amethocaine; dex $=0.1 \%$ dexamethasone; keto $=$ ketorolac; brim $=0.2$ or $0.15 \%$ brimonidine; fluoro $=0.1 \%$ fluorometholone; pilo $=1 \%$ pilocarpine; $4 x=4$ times daily; $5 d=$ for 5 days; $7 d=$ for 7 days 
synechiae, hyphema, severe uveitis or persistent IOP rise are very rare.

\section{Topics to be addressed in the future}

Further investigation is needed to demonstrate if SLT can be repeated enough to maintain IOP under control for decades on end. Possibly, the future of SLT lies in a yearly application of a smaller number of spots, as is currently under investigation by Gandolfi et al. (Vienna, SOE meeting, 2015).

In conclusion, SLT may be introduced into glaucoma management algorithms in two ways. First, as a primary treatment to patients with OAG, comparable in efficacy to medication. Second, as a treatment alternative for patients not controlled with maximally tolerated medication, before invasive surgery.

\section{Competing interests}

The authors declare that they have no competing interests.

\section{Authors' contributions}

MDK conceived and designed the study, acquired all data, drafted and revised the manuscript. MDB performed data analysis, statistical analysis and revision of the manuscript. SDB helped to design the study, critically revised the manuscript and gave material and administrative support. VDG contributed to the design of the study, performed critical revision and supervision of the manuscript and study. All authors read and approved the final manuscript.

\section{Author details}

'Department of Medicine, University of Antwerp, Universiteitsplein 1, B-2610 Antwerp, Belgium. ${ }^{2}$ Medipolis, Boomsesteenweg 223, B-2610 Antwerp, Belgium. ${ }^{3}$ Faculty of Psychology and Education, Department of Experimental Psychology, Ghent University, Henri Dunantlaan 2, B-9000 Ghent, Belgium. ${ }^{4}$ Department of Ophthalmology, University Hospital Antwerp, Wilrijkstraat 10, B-2650 Edegem, Belgium.

Received: 1 November 2015 Accepted: 15 March 2016

Published online: 05 April 2016

\section{References}

1. Everitt DE, Avorn J. Systemic effects of medications used to treat glaucoma. Ann Intern Med. 1990;112(2):120-5.

2. Chauhan BC, Mikelberg FS, Artes PH, Balazsi AG, LeBlanc RP, Lesk MR, et al. Canadian Glaucoma Study: 3. Impact of risk factors and intraocular pressure reduction on the rates of visual field change. Arch Ophthalmol. 2010;128(10):1249-55.

3. Quigley HA, Broman AT. The number of people with glaucoma worldwide in 2010 and 2020. Br J Ophthalmol. 2006;90(3):262-7.

4. Robin AL, Novack GD, Covert DW, Crockett RS, Marcic TS. Adherence in Glaucoma: Objective Measurements of Once-Daily and Adjunctive Medication Use. Am J Ophthalmol. 2007:144(4):533-40.

5. Cantor LB, Katz L, Cheng JW, Chen E, Tong KB, Peabody JW. Economic evaluation of medication, laser trabeculoplasty and filtering surgeries in treating patients with glaucoma in the US. Curr Med Res Opin. 2008;24(10):2905-18.

6. Pisella PJ, Pouliquen P, Baudouin C. Prevalence of ocular symptoms and signs with preserved and preservative free glaucoma medication. $\mathrm{Br}$ J Ophthalmol. 2002;86(4):418-23.

7. Baudouin C. Detrimental effect of preservatives in eyedrops: implications for the treatment of glaucoma. Acta Ophthalmol. 2008;86(7):716-26.

8. Li X, Wang W, Zhang X. Meta-analysis of selective laser trabeculoplasty versus topical medication in the treatment of open-angle glaucoma. BMC Ophthalmol. 2015;15:107.

9. Nagar M. Selective Laser Trabeculoplasty. Journal of Current Glaucoma Practice. 2007;1(2):30-4.
10. Stone $J$, Robin AL, Novack GD, Covert DW, Cagle GD. An objective evaluation of eyedrop instillation in patients with glaucoma. Arch Ophthalmol. 2009;127(6):732-6.

11. Day DG, Sharpe ED, Atkinson MJ, Stewart JA, Stewart WC. The clinical validity of the treatment satisfaction survey for intraocular pressure in ocular hypertensive and glaucoma patients. Eye (Lond). 2006;20(5):583-90.

12. Ting NS, Li Yim JF, Ng JY. Different strategies and cost-effectiveness in the treatment of primary open angle glaucoma. Clinicoecon Outcomes Res. 2014;6:523-30.

13. Wise JB, Witter SL. Argon laser therapy for open-angle glaucoma. A pilot study. Arch Ophthalmol. 1979;97(2):319-22.

14. Wilensky JT, Weinreb RN. Early and late failures of argon laser trabeculoplasty. Arch Ophthalmol. 1983;101(6):895-7.

15. Cvenkel B, Hvala A. Drnov ek-Olup B, Gale N. Acute ultrastructural changes of the trabecular meshwork after selective laser trabeculoplasty and low power argon laser trabeculoplasty. Lasers Surg Med. 2003;33(3):204-8.

16. Bylsma SS, Samples JR, Acott TS, Van Buskirk EM. Trabecular cell division after argon laser trabeculoplasty. Arch Ophthalmol. 1988;106:544-7.

17. Bradley JM, Anderssohn AM, Colvis CM, Parshley DE, Zhu XH, Ruddat MS, et al. Mediation of laser trabeculoplasty-induced matrix metalloproteinase expression by IL-1 beta and TNFalpha. Invest Ophthalmol Vis Sci. 2000:41:422-30.

18. Hodge WG, Damji KF, Rock W, Buhrmann R, Bovell AM, Pan Y. Baseline IOP predicts selective laser trabeculoplasty success at 1 year post-treatment: results from a randomised clinical trial. Br J Ophthalmol. 2005;89(9):1157-60.

19. Mcllraith I, Strasfeld M, Colev G, Hutnik CM. Selective laser trabeculoplasty as initial and adjunctive treatment for open-angle glaucoma. J Glaucoma. 2006;15(2):124-30

20. Latina MA, Sibayan SA, Shin DH, Noecker RJ, Marcellino G. Q-switched 532$\mathrm{nm} \mathrm{Nd:YAG} \mathrm{laser} \mathrm{trabeculoplasty} \mathrm{(selective} \mathrm{laser} \mathrm{trabeculoplasty)} \mathrm{-} \mathrm{a}$ multicentre, pilot, clinical study. Ophthalmology. 1998;105(11):2082-8.

21. Katz LJ, Steinmann WC, Kabir A, Molineaux J, Wizov SS, Marcellino G, et al. Selective laser trabeculoplasty versus medical therapy as initial treatment of glaucoma: a prospective, randomized trial. J Glaucoma. 2012;21:460-8.

22. Lai JS, Chua JK, Tham CC, Lam DS. Five-year follow up of selective laser trabeculoplasty in Chinese eyes. Clin Experiment Ophthalmol. 2004;32(4):368-72.

23. Nagar M, Ogunyomade A, O'Brart DP, Howes F, Marshall J. A randomised, prospective study comparing selective laser trabeculoplasty with latanoprost for the control of intraocular pressure in ocular hypertension and open angle glaucoma. Br J Ophthalmol. 2005;89(11):1413-7.

24. Nagar $\mathrm{M}$, Luhishi $\mathrm{E}$, Shah $\mathrm{N}$. Intraocular pressure control and fluctuation: the effect of treatment with selective laser trabeculoplasty. Br J Ophthalmol. 2009;93(4):497-501.

25. Wong MO, Lee JW, Choy BN, Chan JC, Lai JS. Systematic review and metaanalysis on the efficacy of selective laser trabeculoplasty in open-angle glacoma. Surv Ophthalmol. 2015;60:36-50.

26. Bovell AM, Damji KF, Hodge WG, Rock WJ, Buhrmann RR, Pan YI. Long term effects on the lowering of intraocular pressure: selective laser or argon laser trabeculoplasty? Can J Ophthalmol. 2011;46:408-13.

27. Liu Y, Birt CM. Argon versus selective laser trabeculoplasty in younger patients. J Glaucoma. 2012;21(2):112-5.

28. Rosenfeld E, Shemesh G, Kurtz S. The efficacy of selective laser trabeculoplasty versus argon laser trabeculoplasty in pseudophakic glaucoma patients. Clin Ophthalmol. 2012;6:1935-40.

29. Kent SS, Hutnik CM, Birt CM, Damji KF, Harasymowycz P, Si F, et al. A randomized clinical trial of selective laser trabeculoplasty versus argon laser trabeculoplasty in patients with pseudoexfoliation. J Glaucoma. 2015;24(5):344-7.

30. Alvarado JA, Alvarado RG, Yeh RF, Franse-Carman L, Marcellino GR, Brownstein MJ. A new insight into the cellular regulation of aqueous outflow: how trabecular meshwork endothelial cells drive a mechanism that regulates the permeability of Schlemm's canal endothelial cells. $\mathrm{Br} J$ Ophthalmol. 2005:89(11):1500-5.

31. Detorakis ET, Tsiklis N, Pallikaris IG, Tsilimbaris MK. Changes in the intraocular pressure of fellow untreated eyes following uncomplicated trabeculectomy Ophthalmic Surg Lasers Imaging. 2011:42:138-43.

32. Damji KF, Shah KC, Rock WJ, Bains HS, Hodge WG. Selective laser trabeculoplasty $\vee$ argon laser trabeculoplasty: a prospective randomised clinical trial. Br J Ophthalmol. 1999;83:718-22.

33. Ayala M, Chen E. Predictive factors of success in selective laser trabeculoplasty (SLT) treatment. Clin Ophthalmol. 2011;5:573-6.

34. Lee JW, Wong MO, Wong RL, Lai JS. Correlation of Intraocular Pressure Between Both Eyes After Bilateral Selective Laser Trabeculoplasty in Open- 
Angle Glaucoma. J Glaucoma. 2016;25(3):e248-52. doi:10.1097/IJG. 0000000000000274.

35. Knickelbein JE, Singh A, Flowers BE, Nair UK, Eisenberg M, Davis R, et al. Acute corneal edema with subsequent thinning and hyperopic shift following selective laser trabeculoplasty. J Cataract Refract Surg. 2014;40(10):1731-5.

36. Lee JW, Ho WL, Chan JC, Lai JS. Efficacy of selective laser trabeculoplasty for normal tension glaucoma: 1 year results. BMC Ophthalmol. 2015;15:1. doi:10. 1186/1471-2415-15-1.

37. Weinand FS, Althen F. Long-term clinical results of selective laser trabeculoplasty in the treatment of primary open angle glaucoma. Eur $J$ Ophthalmol. 2006;16(1):100-4.

38. Singh D, Coote MA, O'Hare F, Walland MJ, Ghosh S, Xie J, et al. Topical prostaglandin analogues do not affect selective laser trabeculoplasty outcomes. Eye (Lond). 2009;23(12):2194-9.

39. Hong BK, Winer JC, Martone JF, Wand M, Altman B, Shields B. Repeat selective laser trabeculoplasty. J Glaucoma. 2009;18(3):180-3.

40. Shazly TA, Latina MA, Dagianis JJ, Chitturi S. Effect of prior cataract surgery on the long-term outcome of selective laser trabeculoplasty. Clin Ophthalmol. 2011;5:377-80

41. Ho CL, Lai JS, Aquino MV, Rojanapongpun P, Wong HT, Aquino MC, et al. Selective Laser Trabeculoplasty for Primary Angle Closure With Persistently Elevated Intraocular Pressure After Iridotomy. J Glaucoma. 2009:18(7):563-6.

42. Ayala M. Intraocular pressure reduction after initial failure of selective laser trabeculoplasty (SLT). Graefes Arch Clin Exp Ophthalmol. 2014;252(2):315-20.

43. Rhodes KM, Weinstein R, Saltzmann RM, Aggarwal N, Kooner KS, Petroll WM, et al. Intraocular pressure reduction in the untreated fellow eye after selective laser trabeculoplasty. Curr Med Res Opin. 2009:25(3):787-96.

44. Lee JY, Lee YK, Moon Jl. Long-Term Outcomes and Predictive Factors for Success of Selective Laser Trabeculoplasty. Journal of the Korean Ophthalmological Society. 2014;55(9):1347-54. doi:10.3341/jkos.2014.55.9.1347.

45. Shazly $T A$, Latina MA. Intraocular pressure response to selective laser trabeculoplasty in the first treated eye vs the fellow eye. Arch Ophthalmol. 2011;129(6):699-702

46. Melamed S, Ben Simon GJ, Levkovitch-Verbin H. Selective laser trabeculoplasty as primary treatment for open-angle glaucoma: a prospective, nonrandomized pilot study. Arch Ophthalmol. 2003;121(7):957-60.

47. Shazly TA, Latina MA, Dagianis JJ, Chitturi S. Effect of central corneal thickness on the long-term outcome of selective laser trabeculoplasty as primary treatment for ocular hypertension and primary open-angle glaucoma. Cornea. 2012;31(8):883-6.

48. Lee R, Hutnik CM. Projected cost comparison of selective laser trabeculoplasty versus glaucoma medication in the Ontario Health Insurance Plan. Can J Ophthalmol. 2006:41(4):449-56.

49. Martinez-de-la-Casa JM, Garcia-Feijoo J, Castillo A, Matilla M, Macias JM, Benitez-del-Castillo JM, et al. Selective vs argon laser trabeculoplasty: hypotensive efficacy, anterior chamber inflammation, and postoperative pain. Eye (Lond). 2004;18(5):498-502.

50. Robin AL. The role of apraclonidine hydrochloride in laser therapy for glaucoma. Trans Am Ophthalmol Soc. 1989;87:729-61.

51. Shazly TA, Smith J, Latina MA. Long-term safety and efficacy of selective laser trabeculoplasty as primary therapy for the treatment of pseudoexfoliation glaucoma compared with primary open-angle glaucoma. Clin Ophthalmol. 2010;5:5-10.

52. Juzych MS, Chopra V, Banitt MR, Hughes BA, Kim C, Goulas MT, et al. Comparison of long-term outcomes of selective laser trabeculoplasty versus argon laser trabeculoplasty in open-angle glaucoma. Ophthalmology. 2004;111(10):1853-9.

53. Sayin N, Alkin Z, Ozkaya A, Demir A, Yazici AT, Bozkurt E, et al. Efficacy of selective laser trabeculoplasty in medically uncontrolled glaucoma. ISRN Ophthalmol. 2013;2013:975281.

54. Harasymowycz PJ, Papamatheakis DG, Latina M, De Leon M, Lesk MR, Damji KF. Selective laser trabeculoplasty (SLT) complicated by intraocular pressure elevation in eyes with heavily pigmented trabecular meshworks. Am J Ophthalmol. 2005;139(6):1110-3.

55. Francis BA, lanchulev T, Schofield JK, Minckler DS. Selective lase trabeculoplasty as a replacement for medical therapy in open-angle glaucoma. Am J Ophthalmol. 2005;140(3):524-5.
56. Kara N, Altan C, Satana B, Altinkaynak H, Bozkurt E, Demirok A, et al. Comparison of selective laser trabeculoplasty success in patients treated with either prostaglandin or timolol/dorzolamide fixed combination. J Ocul Pharmacol Ther. 2011;27(4):339-42.

57. Ong K, Ong L, Ong LB. Corneal endothelial abnormalities after selective laser trabeculoplasty (SLT). J Glaucoma. 2015;24(4):286-90.

58. Lee JW, Chan JC, Chang RT, Singh K, Liu CC, Gangwani R, et al. Corneal changes after a single session of selective laser trabeculoplasty for openangle glaucoma. Eye (Lond). 2014;28(1):47-52.

59. Regina M, Bunya VY, Orlin SE, Ansari H. Corneal edema and haze after selective laser trabeculoplasty. J Glaucoma. 2011;20(5):327-9.

60. Ozkok A, Tamcelik N, Ucar Comlekoglu D, Iskeleli G. Corneal decompensation after selective laser trabeculoplasty. Case Rep Ophthalmol Med. 2014;2014:851971.

61. Wu ZQ, Huang J, Sadda S. Selective laser trabeculoplasty complicated by cystoid macular edema: report of two cases. Eye Sci. 2012;27(4):193-7.

62. Wechsler DZ, Wechsler IB. Cystoid macular oedema after selective laser trabeculoplasty. Eye (Lond). 2010;24(6):1113.

63. Kim DY, Singh A. Severe iritis and choroidal effusion following selective laser trabeculoplasty. Ophthalmic Surg Lasers Imaging. 2008;39(5):409-11.

64. Rhee DJ, Krad O, Pasquale LR. Hyphema following selective laser trabeculoplasty. Ophthalmic Surg Lasers Imaging. 2009:40(5):493-4.

\section{Submit your next manuscript to BioMed Central and we will help you at every step:}

- We accept pre-submission inquiries

- Our selector tool helps you to find the most relevant journal

- We provide round the clock customer support

- Convenient online submission

- Thorough peer review

- Inclusion in PubMed and all major indexing services

- Maximum visibility for your research

Submit your manuscript at www.biomedcentral.com/submit
() Biomed Central 